\title{
Characteristics and Origin of Organic Matter in Triassic Lacustrine Shale From Fuxian Oilfield
}

\author{
Fan Bojiang * \\ School of Petroleum Engineering and Environmental Engineering, Yan'an University, Yan'an, China
}

OPEN ACCESS

Edited by:

Yuwei Li,

Liaoning University, China

Reviewed by:

Yangyang $\mathrm{Li}$,

C\&C Reservoirs, United States

Bo Liu,

Northeast Petroleum University, China

Yingchun Guo,

Chinese Academy of Geologi-cal

Sciences (CAGS), China

*Correspondence:

Fan Bojiang

632258611@qq.com

Specialty section: This article was submitted to

Economic Geology,

a section of the journal

Frontiers in Earth Science

Received: 04 August 2021 Accepted: 20 September 2021

Published: 25 October 2021

Citation:

Bojiang F (2021) Characteristics and

Origin of Organic Matter in Triassic

Lacustrine Shale From Fuxian Oilfield.

Front. Earth Sci. 9:752954.

doi: 10.3389/feart.2021.752954
Along with the successful exploitation of shale oil, organic-rich shale has attracted great attention to the geologists. However, quantitatively differentiating the origin of organic matter in shale is still challenging due to the nature of its complex depositional processes. Organic matter in lacustrine shales could be derived from both lake water (produced by lake water column) and land input (transported into the lake by rivers). The Triassic Chang7 shale in the Yanchang Formation is a typical lacustrine shale deposited in the central part of the Ordos Basin. It is rich in organic matter (TOC of $0.52-9.37 \%$ ) and consists primarily of type $\|_{1}$ kerogen. The Chang- 7 shale is thermally mature and currently in the stage of generating oil and gas, with more structured than organic matter. In this study, quantitative models of organic matter in the Chang- 7 shale with sources from both lake water and land is established using geochemical and carbon isotopes data and the results show that lake water and land input have the almost equal contribution to the organic enrichment in the study area.

Keywords: lacustrine shale, organic matters, different origins, mathematical model, fuxian oilfield

\section{INTRODUCTION}

Along with the successful exploitation of shale oil, organic-rich shale has attracted more and more attention to the petroleum geologists (Fink et al., 2018; Awan et al., 2020). Previous researchers have done a lot of investigation on the conditions of organic matter enrichment, and established corresponding interpretational models. The most popular models include: 1) organic matter is easy to be preserved in reducing environments, thus the enrichment of organic matter is related to reducing environment (Awan et al., 2020); 2) the higher the paleo-productivity is, the more organic matter can be provided, thus the enrichment of organic matter is related to paleo-productivity (Liu et al., 2017);3) the enrichment of organic matter depends on both reducing environment and paleoproductivity (Demaison and Moore, 1980).

There is little doubt that the development of organic-rich shale is mainly controlled by sedimentary environments. Organic-rich shale tends to be deposited and preserved under conditions of anoxic water column, high primary productivity and rapid burial rate (Henderson, 2004; Piper and Perkins, 2004; Keighley et al., 2018). However, if a stable supply of organic matter exists, organic-rich shale can also be deposited in a relatively oxidized environment (Abaturov et al., 2018).

In the central part of the Ordos Basin, the Triassic Yanchang Formation was deposited in a lacustrine environment, and a set of organic-rich shales are developed within the Chang-7 member (i.e., Chang-7 shale) (Figure 1) (Fan and Shi, 2019). The Chang-7 shale is characterized by high organic matter content and good hydrocarbon generation potential. However, it is relatively thin, 


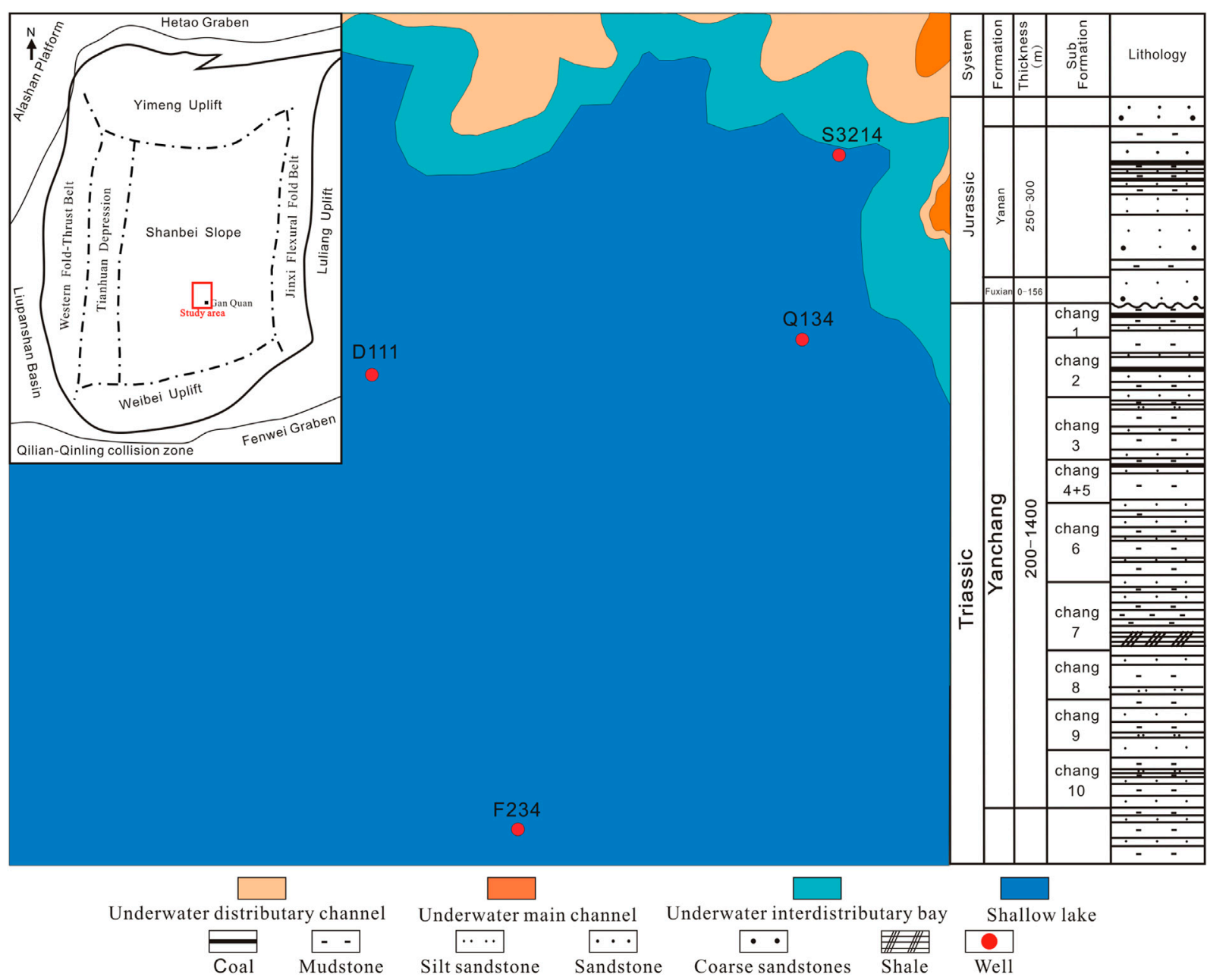

FIGURE 1 | Map showing the location and paleogeography of the study area. A stratigraphic and lithological column of Triassic Chang-7 shale as part of the Yanchang Formation is also shown on the right.

having thicknesses of only 2-10 m). Since 2016, three exploration wells in the study area have obtained industrial oil flow in the Chang-7 shale, and the average daily production rate is $>7$ BOPD. Organic matter in the Chang-7 shale are sourced from both the lake-water column and terrestrial input transported by rivers. Therefore, to determine the contributions from each of the sources in a quantitative way, a mathematical model is established to characterized organic matter in the Chang-7 shale in the central part of the Ordos Basin (Figure 1).

Whole rock X-ray diffraction (XRD) measurements are carried out to obtain the mineral compositions of the Chang-7 shale, and the measured values of 17 samples vary greatly (Table 1). Clay minerals in the Chang-7 shale ranges 27.8-70.3\% (average 54.95\%). Quartz ranges 12.9-29.3\%, (average 19.7\%). K-feldspar content ranges $1.1-5.3 \%$ (average 3.3\%). Plagioclase ranges 4.9-27.9\% (average 12.5\%). Pyrite ranges $0.5-16.2 \%$ (average $3.6 \%)$. These figures indicate that the Chang-7 shale contains a high content of clay minerals but low content of brittle minerals (e.g., quartz, feldspar and plagioclase).

\section{CHARACTERISTICS OF ORGANIC MATTERS}

\section{Microscopic Characteristics}

Organic matter in the Chang-7 shale can be classified into two types based on their morphology through microscopic observations: morphological organic matter and amorphous organic matter. Among the 27 samples in the study area, 24 have morphological organic matter and only 3 have amorphous organic matter. The morphological organic matter often develops in the homogeneous pure shale, while the amorphous organic matter often develops in the sandy shales. Analysis of the energy spectrum images shows that there are great differences in their compositions within different types of organic matter. In morphological organic matter, carbon content is always higher than that of other elements (Figures 2A,B), while in amorphous organic matter, the contents of $\mathrm{Si}, \mathrm{Al}$ and other elements can be higher than that of carbon element (Figures 2C,D). 
TABLE 1 | Mineral compositions of Chang-7 shale.

\begin{tabular}{|c|c|c|c|c|c|c|c|c|}
\hline \multirow[t]{2}{*}{ Well } & \multirow{2}{*}{$\begin{array}{c}\text { Burial depth } \\
\text { (m) }\end{array}$} & \multicolumn{7}{|c|}{ Minerals (\%) } \\
\hline & & Quartz & K-feldspar & Plagioclase & Calcite & Pyrite & Clay & Others \\
\hline Q71 & $1,434.9$ & 29.3 & 5.2 & 27.9 & 9 & - & 27.8 & 30.1 \\
\hline D199 & $1,365.98$ & 21.5 & - & 17.8 & 7 & 0.5 & 49 & 25.7 \\
\hline D199 & $1,372.83$ & 13.1 & 1.8 & 13 & 1.5 & 16.2 & 45.8 & 21.7 \\
\hline D199 & $1,334.28$ & 14 & 2.7 & 6.9 & - & - & 70.3 & 20.1 \\
\hline D199 & $1,352.98$ & 19.5 & 5.3 & 16.4 & 1.9 & - & 54.5 & 21.9 \\
\hline Q71 & $1,422.22$ & 19 & 3.1 & 13.1 & 3.1 & 3.2 & 51.3 & 26.2 \\
\hline Q71 & $1,429.82$ & 24.6 & 3.4 & 14.5 & 0.4 & 4.4 & 45.3 & 32 \\
\hline D199 & $1,373.15$ & 19.1 & 1.5 & 4.9 & - & 1.7 & 69.7 & 22.2 \\
\hline Q71 & $1,427.26$ & 19.1 & 3.6 & 15 & - & 1.7 & 52.6 & 27.1 \\
\hline Q71 & $1,428.45$ & 20 & 4.8 & 11.2 & 0.5 & 1.2 & 57.9 & 24.4 \\
\hline Q71 & $1,429.5$ & 20.4 & 4.4 & 11.6 & 5.6 & 1.3 & 55.7 & 21.4 \\
\hline Q71 & $1,430.5$ & 17.6 & 4 & 11.1 & 4.6 & 1.2 & 57.2 & 21.9 \\
\hline Q129 & $1,657.58$ & 23.9 & 5.3 & 10.5 & 0.4 & - & 56.5 & 27.3 \\
\hline Q129 & $1,658.66$ & 15.8 & 1.9 & 13 & - & 0.7 & 64.8 & 19.6 \\
\hline Q129 & $1,664.78$ & 23.2 & 2.5 & 9.2 & - & 1.5 & 59.7 & 27.1 \\
\hline W100 & $2,009.43$ & 12.9 & 1.6 & 7.1 & 1.7 & 7.5 & 63.9 & 18.2 \\
\hline W100 & 2,009.9 & 22.1 & 1.1 & 10 & - & 5.3 & 52.1 & 31.5 \\
\hline
\end{tabular}

As the organic matter in the study area is mainly morphological, this study will focus on the morphological organic matter. Organic matter deposited in between brittle minerals is commonly filled with pyrite, some of which has organic pores (Figures 3A-C). However, organic pores are overall poorly developed in the 27 samples in the study area. Previous studies show that organic matter is commonly associated with pyrite in the Chang-7 shale of Ordos Basin as in this study, which is interpreted to have been mainly controlled by the paleo-water column (Er et al., 2016; Yuan et al., 2017). Organic matter deposited in between clay minerals has welldeveloped organic pores and no pyrite is observed (Figures 3D-F).

Organic matter can be highly enriched where brittle minerals and clay minerals are both in place (Figures 3G-I). It should be noted that organic matter in these places has the most developed organic pores compared with the organic matter in solely brittle mineral particles or clay minerals. In addition, intergranular pores and intragranular pores are better developed in places where brittle mineral particles and clay minerals are both developed (Figures 3G-I). Some scholars have explained this phenomenon using the hydrocarbon generation and expulsion processes (Tagiyev et al., 1997; Giliazetdinova et al., 2017). However, the current viewpoints on hydrocarbon generation and expulsion is highly controversial due to the complexity of this process (Mann, 1989; Huo et al., 2015). For example, the evolution process of organic matter during hydrocarbon generation has not been described in detail and the hydrocarbon expulsion processes have not been proved (Siddiqui and Lake, 1992; Rong, 2003; Alaug, 2011; Dong et al., 2014).

\section{Organic Matter Abundance, Type and Maturity}

A total of 25 shale samples were collected from 11 exploration wells in the study area for testing and analysis. The tests include measuring organic carbon content, rock pyrolysis parameters, and carbon isotope of shale carbonate. The organic carbon content was measured using Automatic Organic Carbon Analyzer (Vario TOC); the rock pyrolysis parameters were measured using Rock-eval 6 Pyrometer; the carbon isotopes were measured using Gas Isotope Ratio Mass Spectrometer (Thermo-finngan MAT253). The test results are shown in Table 2.

Total organic carbon in the study area ranges from 0.52 to $9.37 \%$ with an average of $2.85 \%$. The samples with TOC $<2.00 \%$ account for $48.00 \%$ of the total samples; the samples with TOC < $4.00 \%$ account for $32.00 \%$ of the total samples; the samples with TOC $>4.00 \%$ account for $20.00 \%$ of the total samples.

Source rock with higher abundance of organic carbon commonly has higher ability in generating hydrocarbons. Therefore, total organic carbon content (TOC) is normally correlated positively with pyrolysis parameters such as free hydrocarbon $\left(\mathrm{S}_{1}\right)$ and pyrolytic hydrocarbon $\left(\mathrm{S}_{2}\right)$. A positive correlation between TOC and $S_{2}$ is also observed in the Chang-7 shale, and the value of $S_{2}$ increases along with the increase of TOC (Figure 4). However, $S_{1}$ has a poor correlation with TOC (Figure 4). Many researchers speculate that this is related to hydrocarbon migration within the source rock (Curtis, 2002) and argue that during the process of hydrocarbon generation and expulsion, free hydrocarbon migrates in a short distance, and the $S_{1}$ obtained in experiment cannot represent all the hydrocarbons generated in-situ (Zeng et al., 2006).

The organic matter in the Chang-7 shale contains type $\mathrm{I}$, type $\mathrm{II}_{1}$ and type $\mathrm{II}_{2}$ kerogen. Among the total 25 samples, 16 of them $(64 \%)$ contains type $\mathrm{II}_{1}$ organic matter; while the other 9 samples (36\%) contain type $\mathrm{I}$ and type $\mathrm{II}_{2}$ organic matter. The maximum pyrolysis temperature of the Chang-7 shale in the study area ranges from 435 to $453^{\circ} \mathrm{C}$ with an average of $444^{\circ} \mathrm{C}$, indicating that Chang7 shale has entered mature stage and is generating oil and gas. Based on the cross plot of Hydrogen Index and Maximum Pyrolysis Temperature, the corresponding vitrinite reflectance is determined to be $0.5-1.2 \%$, which confirms that the Chang-7 shale is in thermal maturity stage and generating oil and gas (Figure 5). 


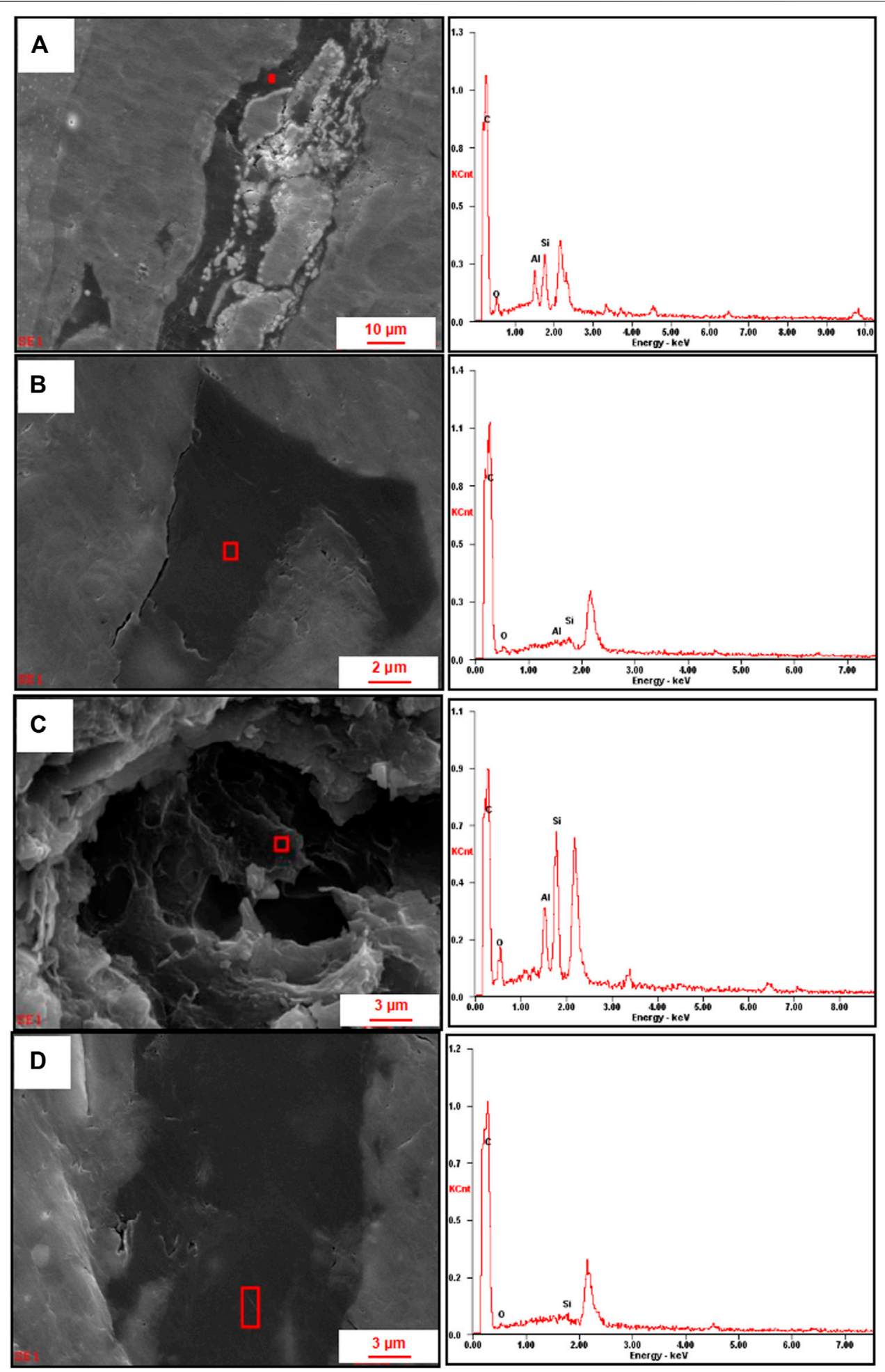

FIGURE 2 | SEM and EDS characteristics of organic matter (A) SEM and energy spectrum photos, showing morphological organic matter is filled with strawberry pyrite, Q129 well, 1667.48 m; (B) SEM and energy spectrum photos, showing morphological organic matter is filled with organic pores, Q129 well, 1667.48 m; (C) SEM and energy spectrum photos, showing coexistence of kaolinite and amorphous organic matter, D19 well, 1369.93 m; (D) SEM and energy spectrum photos, showing amorphous organic matter with organic pores, Q12 well, $1667.48 \mathrm{~m}$. 

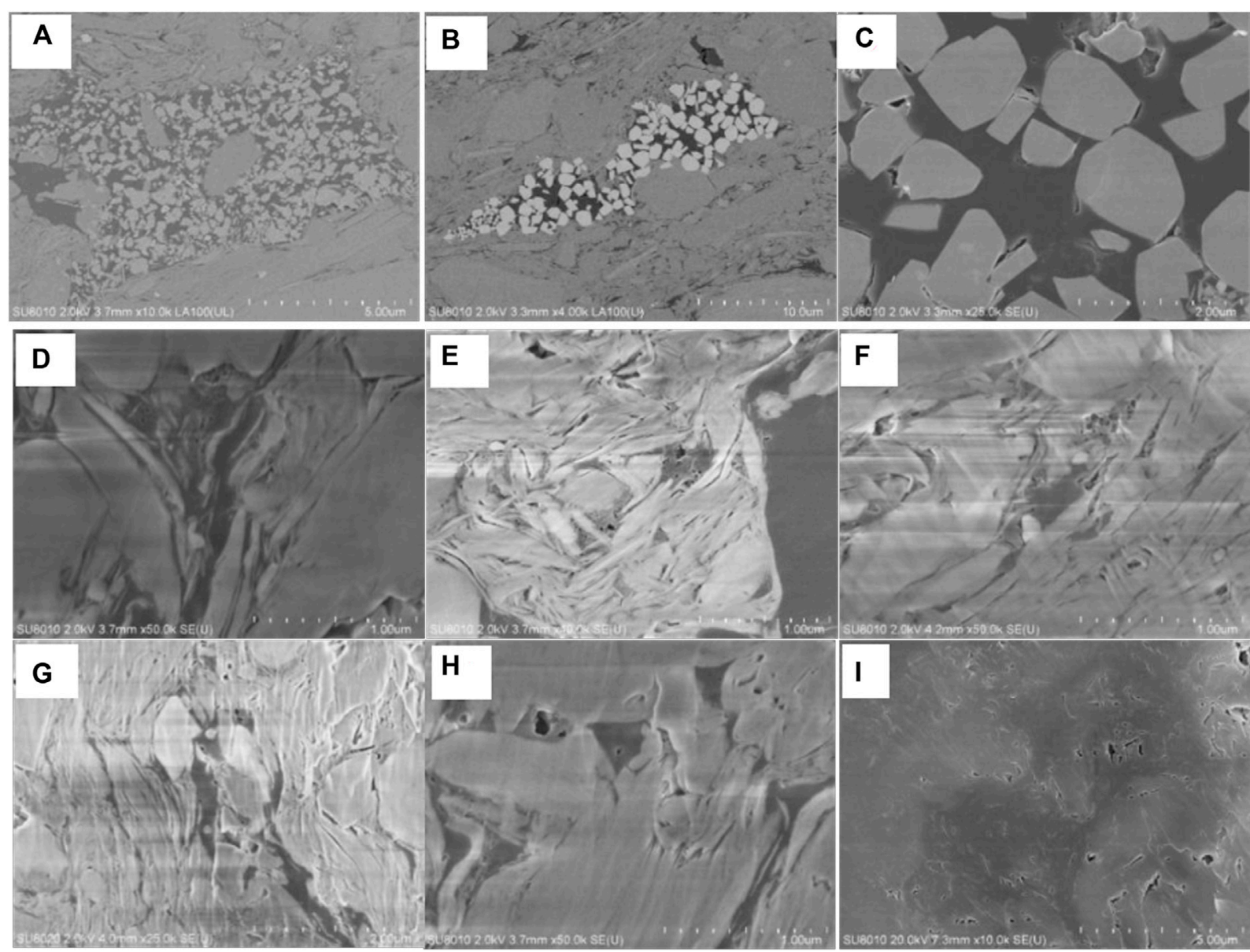

FIGURE 3 | Field emission SEM characteristics of organic matter (A) FE-SEM image showing pyrite and organic pores in organic matter, Q71 well, 1428.84 m; (B) FE-SEM image showing strawberry pyrite in organic matter, Q129 well, 1661.18 m; (C) FE-SEM image showing pyrite and organic pores in organic matter, Q129 well, 1661.18 m; (D) FE-SEM image showing organic matter with organic pores in clay minerals, Q71 well, 1428.84 m; (E) FE-SEM image showing organic matter with organic pores in clay minerals, Q71 well, 1428.84 m; (F) FE-SEM image showing organic matter with organic pores in clay minerals, Q71 well, 1427.94 m; (G) FESEM image showing organic matter in between clay minerals and brittle minerals, with highly developed intergranular pores, intragranular pores and organic pores, D199 well, 1372.59 m; (H) FE-SEM image showing organic matter in between clay minerals and brittle minerals, with highly developed intergranular pores, intragranular pores and organic pores, Q71 well, 1428.84 m; (I) FE-SEM image showing organic matter in between clay minerals and brittle minerals, with highly developed intergranular pores, intragranular pores and organic pores, W104 well, $1363.96 \mathrm{~m}$.

Soluble hydrocarbons range $0.48-11.27 \mathrm{mg} / \mathrm{g}$ (average of $3.77 \mathrm{mg} / \mathrm{g}$ ). Pyrolysis hydrocarbons range $1.66-18.75 \mathrm{mg} / \mathrm{g}$ (average $7.63 \mathrm{mg} / \mathrm{g}$ ). Total hydrocarbon ranges $2.14-25.40 \mathrm{mg} /$ g (average $11.40 \mathrm{mg} / \mathrm{g}$ ). The hydrogen index ranges $117.51-678.85 \mathrm{mg} / \mathrm{g}$ (average $332.81 \mathrm{mg} / \mathrm{g}$ ). Based on the organic matter abundance and type, thermal maturity, and pyrolysis parameters, the Chang-7 shale in the study area is regarded as a high-quality source rock.

\section{Origins of Organic Matters}

Organic matter in lacustrine shale could be derived from a lake water origin or terrestrial origin, or more commonly from both. Lake water contains a lot of nutrients, which feeds a large number of aquatic organisms that can reproduce in water. These aquatic organisms provide an important organic matter supply to the shale deposits (Liu et al., 2017; Liu et al., 2021). As fluvial and alluvial facies developed around the lake, a large number of terrestrial higher plants can be transported through rivers into the lake, which provides another important source of organic matter for lake sediments (Awan et al., 2020).

Based on core data and microscopic observations, the organic matter in the Chang-7 shale the study area are derived from both lake water and land input through river transportation. Core analysis shows that a large number of higher plant debris can be observed, which is a direct indicator of a terrestrial origin of the organic material (Figures 6A,B). Most of the higher plant debris in the Chang-7 shale is continuously distributed, which is probably due to the transportation of plants into the lake (Figures 6C,D). A large number of fish scale fossils can be found in the Chang-7 shale. These fish scales are mainly fanshaped and angular-shaped, and their distribution tends to be clustered and patchy (Figures 6E). Complete fish fossils are also found occasionally in the Chang-7 shale (Figures 6F). The existence of fish, which require a large number of planktons 
TABLE 2 | Geochemical parameters of organic matter in the Chang-7 shale.

\begin{tabular}{|c|c|c|c|c|c|c|c|c|c|c|}
\hline Well & Burial depth (m) & TOC (\%) & $S_{1}(\mathrm{mg} / \mathrm{g})$ & $\mathrm{S}_{2}(\mathrm{mg} / \mathrm{g})$ & $\operatorname{Tmax}\left({ }^{\circ} \mathrm{C}\right)$ & HI (mg/g) & $\mathbf{R}$ & $Q_{1}$ & $\mathbf{Q}_{2}$ & $\mathbf{Q}$ \\
\hline D111 & $1,762.17$ & 9.37 & 0.72 & 12.35 & 449 & 131.80 & 0.33 & 0.98 & 1.98 & 2.96 \\
\hline D314 & $1,107.23$ & 2.57 & 2.83 & 3.02 & 452 & 117.51 & 0.51 & 0.91 & 0.87 & 1.78 \\
\hline S3214 & $1,143.27$ & 5.14 & 1.14 & 6.12 & 453 & 119.07 & 0.43 & 0.89 & 1.18 & 2.08 \\
\hline D299 & $1,371.15$ & 2.91 & 2.78 & 7.29 & 441 & 250.52 & 0.38 & 0.75 & 1.22 & 1.97 \\
\hline F234 & $1,557.24$ & 1.63 & 2.36 & 4.14 & 442 & 253.99 & 0.47 & 0.88 & 0.99 & 1.86 \\
\hline D214 & $1,253.14$ & 7.62 & 6.65 & 18.75 & 441 & 246.06 & 0.36 & 0.99 & 1.77 & 2.76 \\
\hline D121 & $1,149.36$ & 2.17 & 4.73 & 6.73 & 438 & 310.14 & 0.42 & 0.89 & 1.23 & 2.13 \\
\hline Q200 & $1,380.68$ & 6.69 & 2.65 & 16.42 & 439 & 245.44 & 0.36 & 0.79 & 1.41 & 2.20 \\
\hline D328 & $1,082.86$ & 2.26 & 2.9 & 7.56 & 435 & 334.51 & 0.45 & 0.97 & 1.19 & 2.16 \\
\hline F234 & $1,561.54$ & 3.42 & 1.93 & 12.37 & 439 & 361.70 & 0.55 & 0.96 & 0.79 & 1.75 \\
\hline F234 & $1,557.27$ & 1.14 & 5.88 & 6.3 & 441 & 552.63 & 0.74 & 0.89 & 0.31 & 1.21 \\
\hline G178 & $1,609.24$ & 2.59 & 1.26 & 10.85 & 437 & 418.92 & 0.6 & 0.85 & 0.57 & 1.42 \\
\hline D111 & $1,762.68$ & 0.88 & 6.46 & 5.81 & 446 & 660.23 & 0.91 & 0.88 & 0.09 & 0.97 \\
\hline W436 & $1,960.57$ & 1.67 & 2.65 & 9.06 & 447 & 542.51 & 0.87 & 0.86 & 0.13 & 0.99 \\
\hline F234 & $1,562.39$ & 1.79 & 3.39 & 12.06 & 448 & 673.74 & 0.93 & 0.91 & 0.07 & 0.98 \\
\hline G178 & $1,609.19$ & 2.67 & 9.65 & 10.82 & 436 & 405.24 & 0.6 & 0.85 & 0.57 & 1.42 \\
\hline Q200 & $1,378.78$ & 0.74 & 0.48 & 1.66 & 439 & 224.32 & 0.57 & 0.90 & 0.68 & 1.58 \\
\hline D299 & $1,353.12$ & 1.82 & 4.05 & 7.18 & 444 & 394.51 & 0.68 & 0.80 & 0.38 & 1.18 \\
\hline D299 & $1,364.78$ & 0.84 & 1.65 & 3.74 & 447 & 445.24 & 0.72 & 0.92 & 0.36 & 1.27 \\
\hline F234 & $1,596.4$ & 4.71 & 7.39 & 9.71 & 446 & 206.16 & 0.42 & 0.92 & 1.28 & 2.20 \\
\hline F234 & $1,560.78$ & 2.56 & 3.74 & 4.74 & 449 & 185.16 & 0.63 & 0.92 & 0.54 & 1.47 \\
\hline Q301 & $1,699.73$ & 1.33 & 2.93 & 2.63 & 445 & 197.74 & 0.52 & 0.93 & 0.86 & 1.79 \\
\hline Q246 & $1,646.76$ & 0.52 & 11.27 & 3.53 & 446 & 678.85 & 0.93 & 0.86 & 0.06 & 0.92 \\
\hline W200 & $1,891.36$ & 1.96 & 1.74 & 2.45 & 445 & 125.00 & 0.35 & 0.92 & 1.70 & 2.61 \\
\hline Q134 & $1,231.26$ & 2.34 & 2.93 & 5.6 & 446 & 239.32 & 0.56 & 0.98 & 0.77 & 1.75 \\
\hline
\end{tabular}

Abbreviations: TOC, Total Organic Carbon; S1, Free Hydrocarbon; S2, Pyrolytic Hydrocarbon; Tmax, Maximum Pyrolysis Temperature; HI, Hydrogen Index; R, Water Organic Matter Ratio; $Q_{1}$, Water Organic Matter Index; $Q_{2}$, Land Organic Matter Index; Q, Total Organic Matter Index.
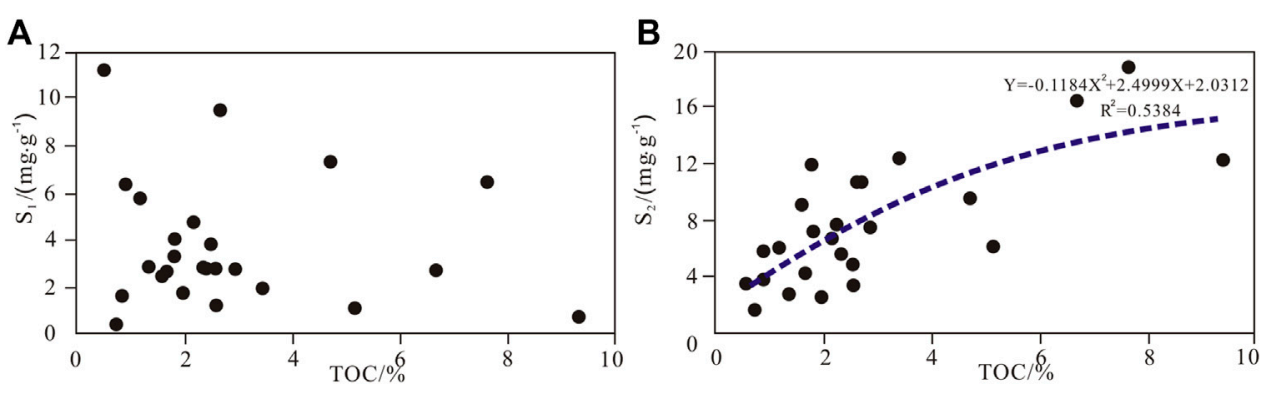

FIGURE 4 | Plots showing the relationship between TOC and pyrolysis parameters (A) TOC versus $\mathrm{S}_{1}$; (B) TOC versus $\mathrm{S}_{2}$.

and algae for survival, indicates that the paleo lake is rich in nutrients (Rowe et al., 2012).

A large number of sporophytes, molluscs and microfauna fossils are observed under the microscope in the Chang 7 shale (Figures 6G,H). Sporophytes and molluscs are characterized by 'dark in the middle and bright in the periphery' under orthogonal polarized light. This is because sporophytes and mollusks have a thin-walled structure, and difference exits between the calcification in the thin crust and the internal portion. Mollusks are typical aquatic organisms. Mollusk fossils are widely observed in the Chang-7 shale and are characterized by a long strip shape (Figures 6G,H). Sporophyte comes from higher plants, and it is an important sign of terrestrial input. Sporophytes in the Chang-7 shale are nearly circular in shape, and their occurrence is either clustered (Figures 6I) or isolated (Figures 6J). The skeleton fossils of microfauna are mainly small remnants of fish scales (Figures $\mathbf{6 H}, \mathbf{K}$ ). Other fossils exist in Chang-7 shale. However, due to the complete destruction of the paleontological morphology, it is almost impossible to identify their original forms based on the remnant fossils (Figure 6L).

More detailed organic matter origins are revealed by biomarker parameters. Figures $\mathbf{2 A - C}$ represent the samples cellected from type $\mathrm{I}$, type $\mathrm{II}_{1}$, type $\mathrm{II}_{2}$ organic matters respectively (Figure 7). According to biogeochemical studies, the carbon distribution of $\mathrm{n}$-alkanes is relatively complete. The TICs exhibit a typical oil-window n-alkane distribution with a peak at $n-C_{15}$ to $n-C_{22}$, and the n-alkanes of most samples show a single peak distribution with no odd-over-even predominance. Compared with large molecule $n$-alkanes (above $\mathrm{C}_{20}$ ), the content of small molecule $n$-alkanes $\left(\mathrm{C}_{20}\right.$ and below $\left.\mathrm{C}_{20}\right)$ is relatively low, with the ratio of $0.59-1.17$ and average ratio of 0.79 , indicating a significant contribution of higher plant input. 


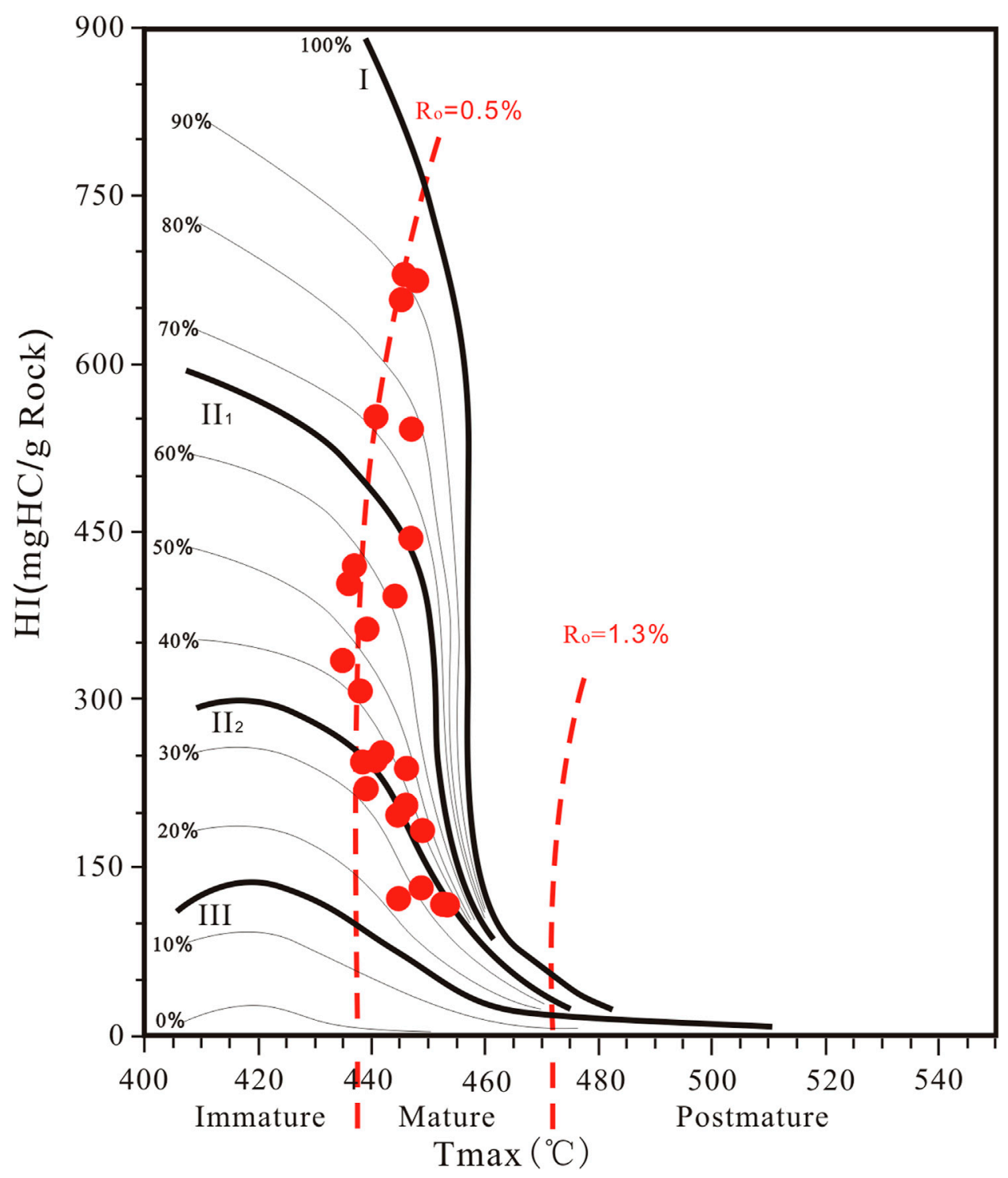

FIGURE 5 | Cross plot of hydrogen Index and maximum pyrolysis temperature, which indicates that the Chang-7 shale is in a mature stage.

Sterane usually originates from higher plants and algae. Thus, the origins of organic matter can also be effectively identified using sterane parameters. The most commonly used method is to determine the origins according to the relative content of regular steranes. $\mathrm{C}_{28}$ regular steranes are closely related to the development of diatoms; $\mathrm{C}_{27}$ regular steranes mainly come from algae; $\mathrm{C}_{29}$ regular steranes come from both algae and higher plants. For lacustrine systems, most of $\mathrm{C}_{27}, \mathrm{C}_{28}$ and $\mathrm{C}_{29}$ regular steranes in liquid hydrocarbons are $\mathrm{V}$-shaped (i.e. $\mathrm{C}_{27}>$ $\mathrm{C}_{28}<\mathrm{C}_{29}$ ), indicating a significant contribution of higher plant input. According to the samples in the study area, the distribution of regular steranes generally meets the above rules (Figure 7). The composition characteristics of $\mathrm{C}_{27}, \mathrm{C}_{28}$ and $\mathrm{C}_{29}$ regular steranes show that the origins of organic matter in shale in the study area is composed of terrestrial plants and lake plankton (Figure 8).
Hydrocarbons formed through thermal maturation of terrestrial organic matter (especially higher plant-derived organic matter) are generally characterized by high ratio of $\mathrm{Pr} / \mathrm{Ph}$. Therefore, it is reliable to use $\mathrm{Pr} / \mathrm{Ph}, \mathrm{C}_{27} / \mathrm{C}_{29}$ sterane, $\mathrm{Pr} / \mathrm{n}-\mathrm{C}_{17}, \mathrm{Ph} / \mathrm{n}-\mathrm{C} 18$ to investigate sedimentary environment (Bushnev et al., 2017; Chiadikobi and Chiaghanam, 2018). Based on the analysis of 38 samples in the study area, there is only a minor variation in the values of $\mathrm{Pr} / \mathrm{n}-\mathrm{C}_{17}$ and $\mathrm{Ph} /$ $\mathrm{n}-\mathrm{C} 18$, proving that the organic matter in Chang-7 shale has a mixed origin (Figure 9). In addition, $\mathrm{Pr} / \mathrm{Ph}$ and $\mathrm{C}_{27} / \mathrm{C}_{29}$ Sterane values also fall into a narrow range (Figure 9B), indicating that organic matter in Chang-7 shale is derived from both aquatic algae and terrestrial plants, and the Chang7 shale was deposited under weakly reducing and weakly oxidizing conditions (Figure 9). 

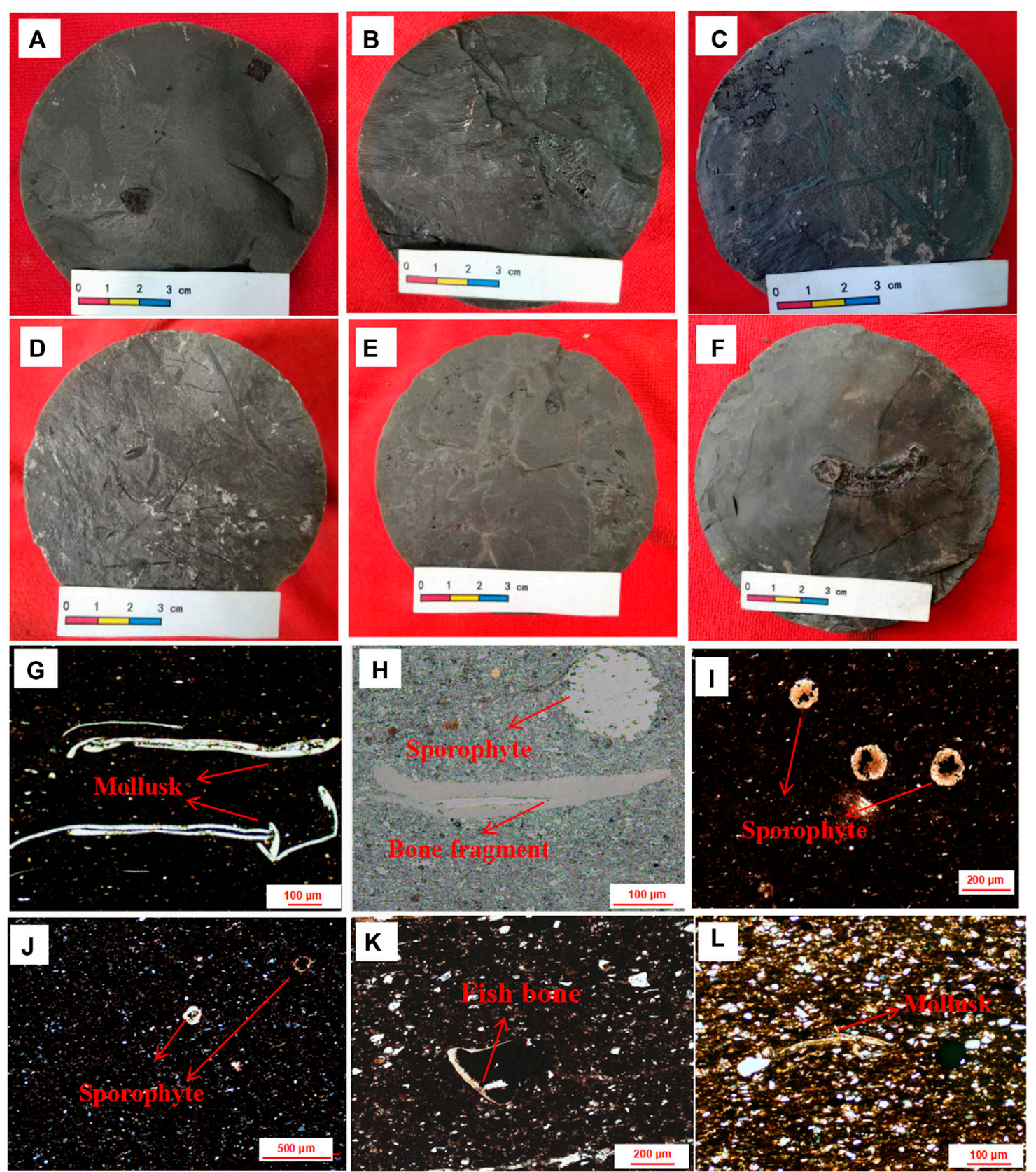

FIGURE 6 | Core and microscopic characteristics of source input (A) core photo showing plant debris (fossils), Z22 well, $1223.91 \mathrm{~m}$; (B) core photo showing abandant plant debris (fossils) and carbonized particles, S31 well, $1152.35 \mathrm{~m}$; (C) core photo showing abandant plant debris (fossils) and carbonized particles, D19 well, $1369.91 \mathrm{~m}$; (D) core photo showing abandant plant debris (fossils), Q208 well, $1080.89 \mathrm{~m}$; (E) core photo showing a large number of fish scales (fossils), Q100 well, $1383.07 \mathrm{~m}$; (F) core photo showing an intact fish (fossils), S31-14 well, $141.16 \mathrm{~m} ;$ (G) cast thin section, Plane-polarized light (10X) showing thin walled calcitic skeletal fragments, possible mollusks. YY1 well, $1315.12 \mathrm{~m}$; (H) cast thin section, right-field reflected light (10X) showing bone fragment (center) and possible spore (upper right), YY1 well, 1374.24 m; (I) cast thin section, single polarization (10X) showing a black shale with sporophyte, YCCV1245 well, $1555.6 \mathrm{~m}$; (J) cast thin section, single polarization (5X) showing a black shale with sporophyte, D11 well, $1762.08 \mathrm{~m}$; (K) cast thin section, single polarization (10X) showing a sandy laminated shale with fossilized fish bone, YCCV1245 well, $1562.63 \mathrm{~m}$; (L) cast thin section, single polarization (10X) showing a thin walled calcitic skeletal fragments, possible mollusk, YY1 well, $1397.66 \mathrm{~m}$. 

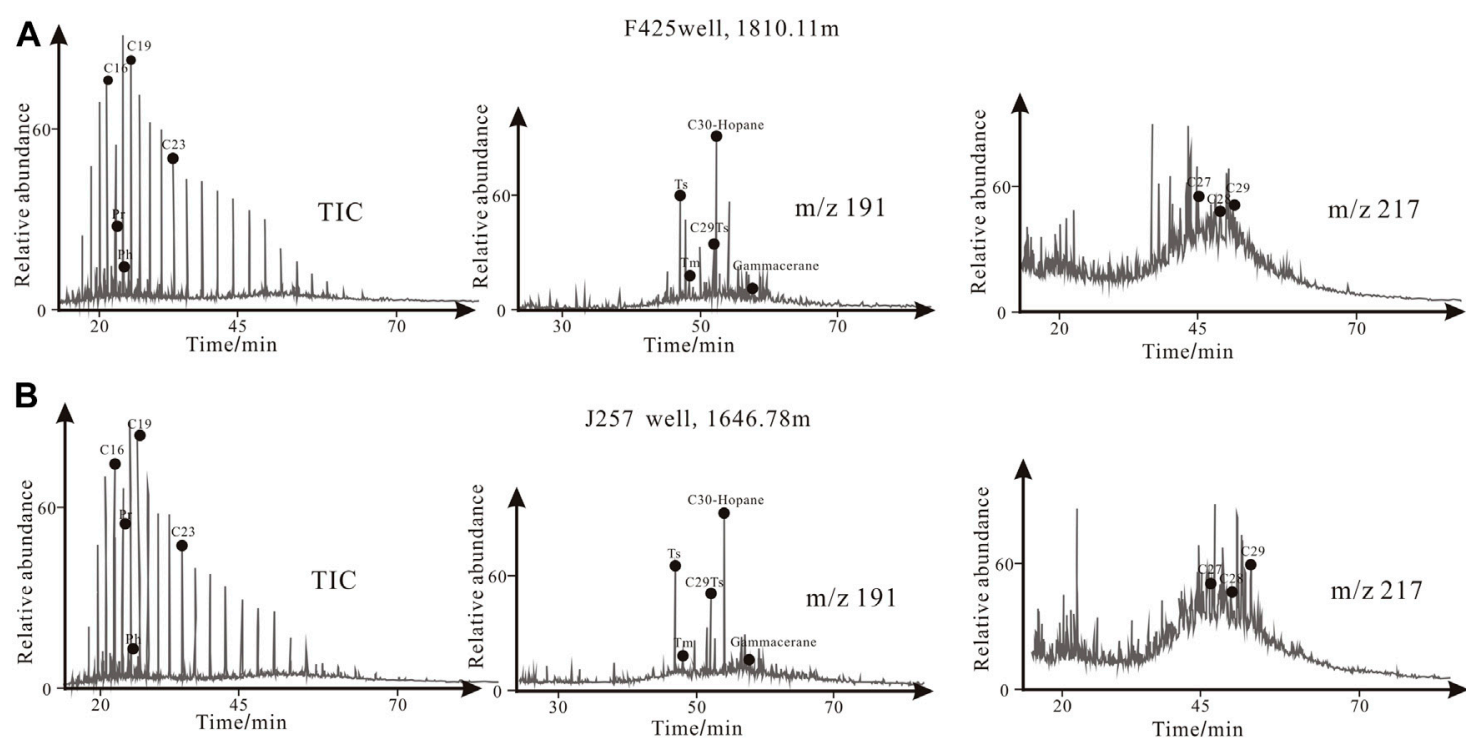

J257 well, $1646.78 \mathrm{~m}$
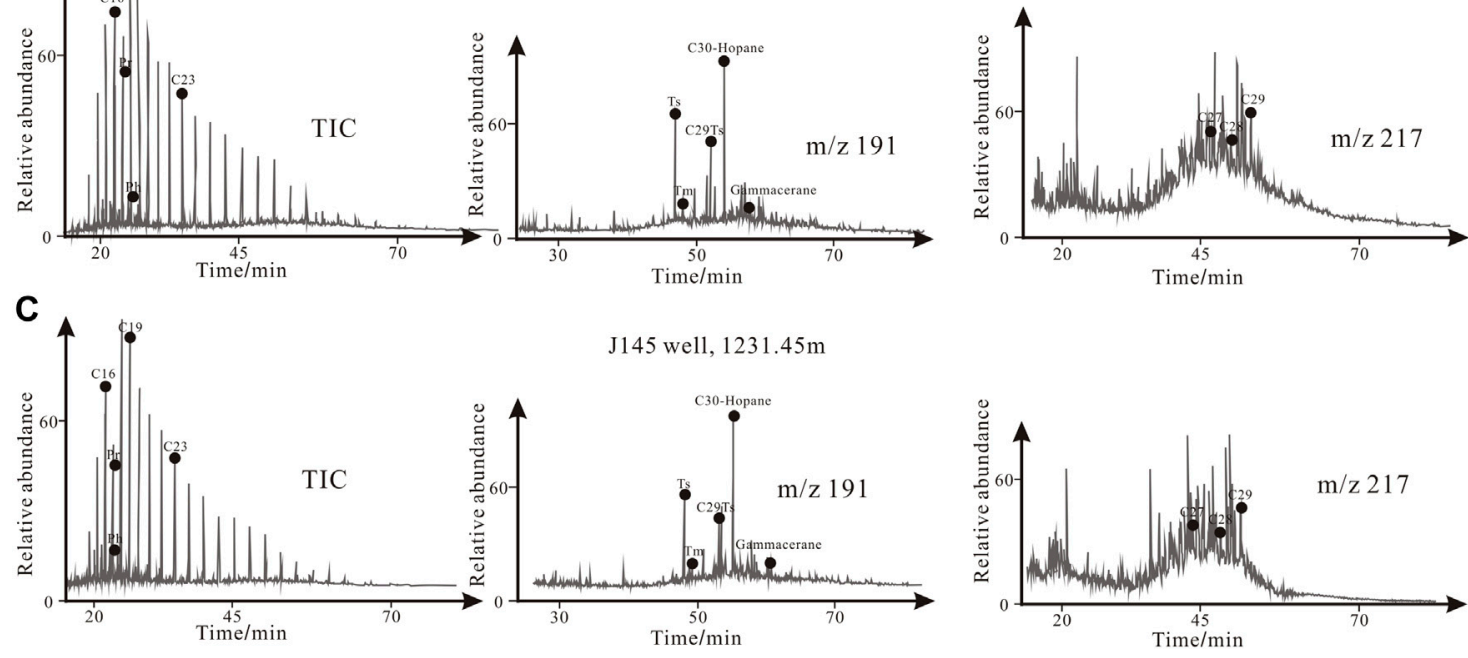

FIGURE 7 | The n-alkane gas chromatograms of saturated hydrocarbon in different organic matters.

\section{QUANTITATIVE STUDY OF MIXED-ORIGIN ORGANIC MATTERS}

\section{Principles of Quantitative Characterization Quantitative Characterization of Organic Matter Originated From Lake Water}

Two stable carbon isotopes exist in natural conditions (i.e., ${ }^{12} \mathrm{C}$ and ${ }^{13} \mathrm{C}$ ) (Li et al., 2017; Ogrinc et al., 2016; Faiz et al., 2018). Through photosynthesis, the concentration of ${ }^{12} \mathrm{C}$ and ${ }^{13} \mathrm{C}$ changes, which is called isotopic fractionation (Li et al., 2017; Ogrinc et al., 2016; Faiz et al., 2018). However, the precipitation of inorganic carbonates is not affected by isotopic fractionation. (Li et al., 2017; Ogrinc et al., 2016; Faiz et al., 2018). Lake water tends to be enriched in ${ }^{13} \mathrm{C}$ as plankton, especially phytoplankton preferably taking ${ }^{12} \mathrm{C}$ during photosynthesis. The enrichment of ${ }^{13} \mathrm{C}$ would result in high $\delta{ }^{13} \mathrm{C}$ in carbonates (McKenzie, 1985; Weissert et al., 2008). $\delta{ }^{13} \mathrm{C}$ in carbonates is calculated using the following equation:

$$
\delta^{13} \mathrm{C}=\left[\frac{\left(\frac{{ }^{13} \mathrm{C}}{{ }^{12} \mathrm{C}}\right)_{\text {sample value }}}{\left[\left(\frac{{ }^{13} \mathrm{C}}{{ }^{12} \mathrm{C}}\right)\right]_{\text {sample value }}}-1\right]
$$

In this Formula, the standard value of $\left({ }^{13} \mathrm{C} /{ }^{12} \mathrm{C}\right)$ is the International PDB Standard (Pee Dee belemnite), $\left({ }^{13} \mathrm{C} /\right.$ $\left.{ }^{12} \mathrm{C}\right)_{\text {standard value }}=1123.7 \times 10^{-5}$.
The concept of "aquatic organic index" is used to characterize the organic matter originated from lake water. aquatic organic index refers to the relative contribution of all kinds of aquatic organisms to the total organic matter within the sediments. The value of aquatic organic index ranges $0-1$ and can be calculated as follows:

$$
\begin{aligned}
\mathrm{Q}_{1}= & \left(\delta^{13}\right. \text { Cmeasured value } \\
& \left.-\delta^{13} \text { Cminimum value }\right) /\left(\delta^{13}\right. \text { Cmaximum value } \\
& \left.-\delta^{13} \text { Cminimum value }\right)
\end{aligned}
$$

$\mathrm{Q}_{1}$ : aquatic organic index; $\delta{ }^{13} \mathrm{C}_{\text {measured value: carbon isotopic values }}$ of carbonate from the measured samples; $\delta{ }^{13} \mathrm{C}_{\text {maximum value: }}$ Maximum value of carbonate carbon isotopes; $\delta^{13} \mathrm{C}_{\text {minimum value }}$ Minimum value of carbonate carbon isotopes.

According to the statistics of carbon isotope in lacustrine shales in China, the average value of $\delta{ }^{13} \mathrm{C}$ maximum value is 10.435 , and the average value of $\delta{ }^{13} \mathrm{C}$ minimum value is -9.003 .

\section{Quantitative Characterization of Organic Matter Originated From Land Input}

The type of organic matter provides qualitative information about their sources. Type I organic matter is primarily produced in situ in the water; type III organic matter is mainly from terrestrial sources, and type II organic matter commonly has a mixed 


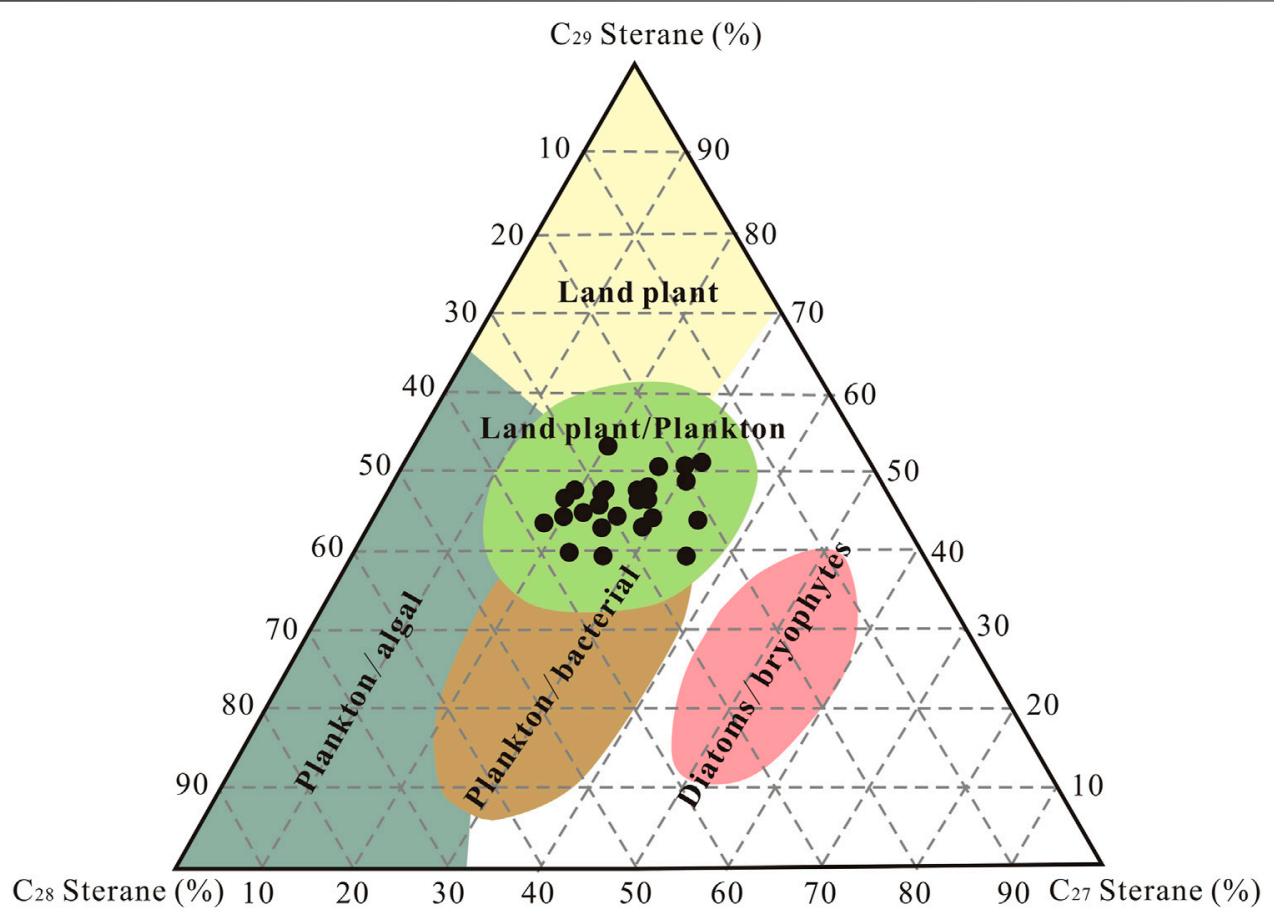

FIGURE 8| Sedimentary environment of shale in study area (A) The relationship between $\mathrm{Pr} / \mathrm{n}-\mathrm{C}_{17}$ and $\mathrm{Ph} / \mathrm{n}-\mathrm{C}_{18} ; \mathbf{( B )}$ The relationship between $\mathrm{Pr} / \mathrm{Ph}$ and $\mathrm{C}_{27} / \mathrm{C}_{29}$.
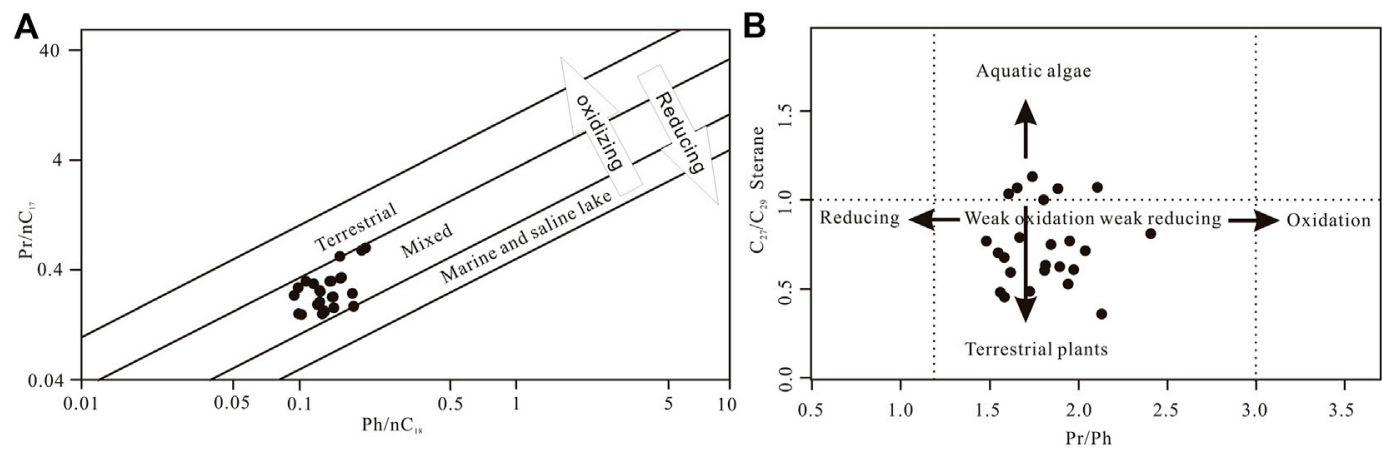

FIGURE 9| Cross plots: (A) Q1 versus TOC; (B) Q2 versus TOC; (C) Q versus TOC; and (D) R versus Hl, giving an indication for the origins of organic matter in the Chang-7 shale in the study area.

source. Recently, many researchers promoted the use of aquatic organic ratio (AOR) to quantitatively evaluate the source of organic matter (Pang et al., 2003; Hu et al., 2018; Awan et al., 2020). AOR is defined as the percentage of organic matter generated in situ in the water body to the total organic matter in the sediments. This method is based on the following assumptions: 1) type I organic matter is $100 \%$ from in situ water body; 2) type III organic matter is $100 \%$ from terrestrial input. Others fall in between 0 and $100 \%$ through interpolation.

With aquatic organic index $\left(Q_{1}\right)$ and aquatic organic ratio $(R)$, terrigenous organic index $\left(Q_{2}\right)$ as defined by the organic matter contributed by terrestrial input can be calculated using the following equation:

$$
\mathrm{Q}_{2}=\mathrm{Q}_{1} \times(1-\mathrm{R}) / \mathrm{R}
$$

Total organic index $\mathrm{Q}$ as the total organic matter productivity in the sediments can be calculated by the sum of $Q_{1}$ and $Q_{2}$ using the following equation:

$$
\mathrm{Q}=\mathrm{Q}_{1}+\mathrm{Q}_{2}
$$

\section{Quantitative Analysis of Organic Origins in the Study Area}

The terrigenous organic index changes greatly in the study area, ranging from 0.06 to 1.98 (Table 2). The reason lies in that the input 

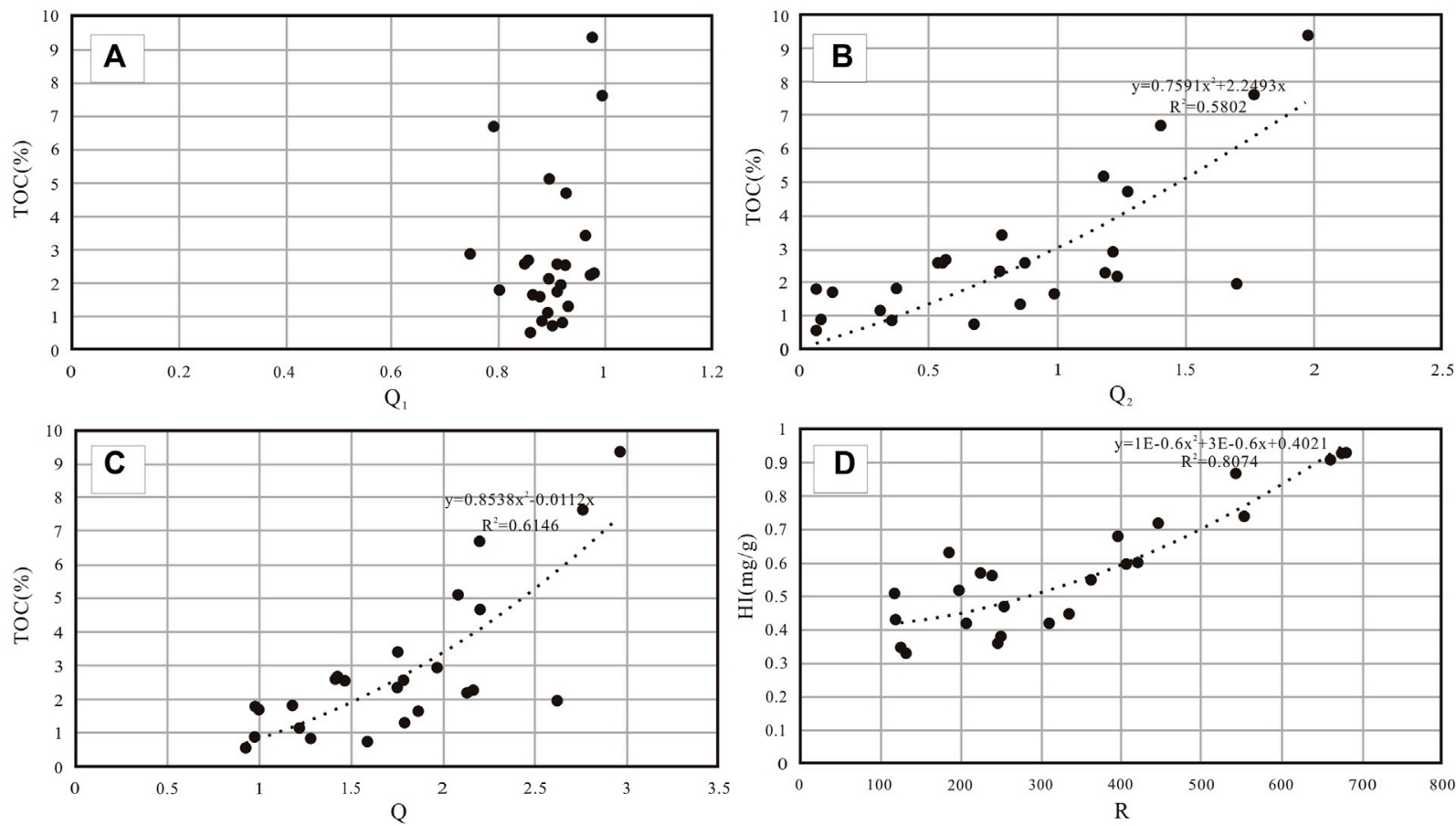

FIGURE 10 | Cross plots: (A) Q1 versus TOC, (B) Q2 versus TOC, (C) Q versus TOC, and (D) R versus HI, giving an indication for the origins of organic matter in the Chang-7 shale in the study area.

of terrigenous materials is controlled by an extremely complex process, which is affected by factors such as volume, rate and sources. Therefore, organic matter originated from terrigenous input commonly have significant variations in geochemical properties. In contrast, the aquatic organic index has little variations in the study area, ranging from 0.75 to 0.99 (only two samples are less than 0.8). This is probably due to the simple chemical nature and weak carbon isotope fractionation in the shallow lake where the Chang-7 shale was deposited (Figure 10).

Calculation based on data from the Chang-7 shale in the study area shows that the average aquatic organic index is 0.89 and the average terrigenous organic index is 0.84 . The terrigenous organic index is very close to that of aquatic organic index. The data and analysis mentioned above indicate that paleo-water column and terrestrial input contributed equally to the enrichment of organic matter in the Chang-7 shale in the study area.

Using data from tests and calculation from 25 samples, a strong positive correlation between the total organic carbon content and total organic matter index can be seen, having a coefficient of 0.6146 . There is also a strong positive correlation between the total organic carbon content and the terrestrial organic index, having a correlation coefficient of 0.5802 (Figure 10). The above observations indicate that the change of total organic index is primarily controlled by terrigenous organic index because there is no significant variations in aquatic organic index. The more input of organic matter from land, the more enriched in organic matter the shale is.
The quantitative analysis mentioned above has its own limitations. Two parameters, maximum value of carbonate carbon isotopes and minimum value of carbonate carbon isotopes, are difficult to be obtained, which limits its feasibility to be applied in other areas or scenarios.

\section{CONCLUSION}

This study shows that the Triassic Chang-7 shale in the central part of the Ordos Basin has high organic abundance. It is thermally mature and is currently generating oil and gas. It contains predominantly type $\mathrm{II}_{1}$ organic matter. The organic matter in the Chang-7 shale is mostly structured other than amorphous. Terrestrial input and paleo-water column contributed equally to the enrichment of organic matter in the Chang-7 shale in the study area.

\section{DATA AVAILABILITY STATEMENT}

The original contributions presented in the study are included in the article/Supplementary Material, further inquiries can be directed to the corresponding author.

\section{AUTHOR CONTRIBUTIONS}

The author confirms being the sole contributor of this work and has approved it for publication. 


\section{FUNDING}

This paper is financially supported by National Natural Science Foundations of Shaanxi Province (Grant No. 2019JQ-308).

\section{REFERENCES}

Abaturov, A. L., Moskalev, I. V., Kiselkov, D. M., and Strelnikov, V. N. (2018). Production of Isotropic Coke from Shale: Microstructure of Coke from the Thermally Oxidized Distillation Residue of Shale Tar. Coke Chem. 61, 433-446. doi:10.3103/s1068364x18110029

Alaug, A. S. (2011). Source Rocks Evaluation, Hydrocarbon Generation and Palynofacies Study of Late Cretaceous Succession at 16/G-1 Offshore Well in Qamar Basin, Eastern Yemen. Arab J. Geosci. 4, 551-566. doi:10.1007/ s12517-010-0182-6

Awan, R. S., Liu, C. L., GongChao, H. W. D., and Chamssidini, L. G. (2020). Paleo-sedimentary Environment in Relation to Enrichment of Organic Matter of Early Cambrian Black Rocks of Niutitang Formation from Xiangxi Area China. Mar. Pet. Geology. 112, 1-20. doi:10.1016/ j.marpetgeo.2019.104057

Bushnev, D. A., Burdel'naya, N. S., and Zhuravlev, A. V. (2017). Organic Matter in Upper Devonian Deposits of the Chernyshev Ridge. Geochem. Int. 55, 548-558. doi:10.1134/s0016702917060027

Chiadikobi, K., and Chiaghanam, O. I. (2018). Biomarker Distributions of the Campano-Maastrichtian Nkporo Group of Anambra Basin, Southeastern Nigeria. Pet. Coal 60, 1161-1175.

Curtis, J. B. (2002). Fractured Shale-Gas Systems. AAPG Bull. 86, 1921-1938. doi:10.1306/61eeddbe-173e-11d7-8645000102c1865d

Demaison, G. J., and Moore, G. T. (1980). Anoxic Environments and Oil Source Bed Genesis. AAPG Bull. 64, 1179-1209. doi:10.1306/2f91945e-16ce-11d7$8645000102 \mathrm{c} 1865 \mathrm{~d}$

Dong, T., He, S., Wang, D., and Hou, Y. (2014). Hydrocarbon Migration and Accumulation in the Upper Cretaceous Qingshankou Formation, Changling Sag, Southern Songliao Basin: Insights from Integrated Analyses of Fluid Inclusion, Oil Source Correlation and basin Modelling. J. Asian Earth Sci. 90, 77-87. doi:10.1016/j.jseaes.2014.04.002

Er, C., Li, Y., Zhao, J., Wang, R., Bai, Z., and Han, Q. (2016). Pore Formation and Occurrence in the Organic-Rich Shales of the Triassic Chang-7 Member, Yanchang Formation, Ordos Basin, China. J. Nat. Gas Geosci. 1, 435-444. doi:10.1016/j.jnggs.2016.11.013

Faiz, M., Zoitsas, A., Altmann, C., Baruch-Jurado, E., and Close, D. (2018). Carbon Isotope Fractionation in Coal and Marine Source Rocks and Implications for Exploration. ASEG Extended Abstr. 2018, 1. doi:10.1071/ ASEG2018abP001

Fan, B., and Shi, L. (2019). Deep-Lacustrine Shale Heterogeneity and its Impact on Hydrocarbon Generation, Expulsion, and Retention: A Case Study from the Upper Triassic Yanchang Formation, Ordos Basin, China. Nat. Resour. Res. 28, 241-257. doi:10.1007/s11053-018-9387-2

Fink, R., Amann-Hildenbrand, A., Bertier, P., and Littke, R. (2018). Pore Structure, Gas Storage and Matrix Transport Characteristics of Lacustrine Newark Shale. Mar. Pet. Geology. 97, 525-539. doi:10.1016/ j.marpetgeo.2018.06.035

Giliazetdinova, D. R., Korost, D. V., and Gerke, K. M. (2017). Studying of Shale Organic Matter Structure and Pore Space Transformations during Hydrocarbon Generation//Advances in Laboratory Testing \& Modelling of Soils \& Shales. Cham: Springer.

Henderson, R. A. (2004). A Mid-cretaceous Association of Shell Beds and Organic-Rich Shale: Bivalve Exploitation of a Nutrient-Rich, Anoxic Sea-Floor Environment. PALAIOS 19, 156-169. doi:10.1669/0883-1351(2004)019<0156:amaosb >2.0.co;2

Huo, Z., Pang, X., Ouyang, X., Zhang, B., Shen, W., Guo, F., et al. (2015). Upper Limit of Maturity for Hydrocarbon Generation in Carbonate Source Rocks in the Tarim Basin Platform, China. Arab J. Geosci. 8, 2497-2514. doi:10.1007/ s12517-014-1408-9

\section{ACKNOWLEDGMENTS}

The authors wish to acknowledge Shaanxi Yanchang Petroleum for providing samples and data.

Keighley, D., Mcfarlane, C., and Vanden Berg, M. (2018). Diagenetic Sequestration of Rare Earths and Actinides in Phosphatic Oil Shale from the Lacustrine Green River Formation (Eocene), Utah, USA: an SEM and LA-ICP-MS Study. J. Paleolimnol 59, 81-102. doi:10.1007/ s10933-016-9905-3

Li, Y., Wang, H., Wang, M. L. P., Duan, T., and Ji, B. (2017). Automatic Identification of Carbonate Sedimentary Facies Based on PCA and KNN Using Logs. Well Logging Technol. 41, 57-63. doi:10.16489/j.issn.10041338.2017.01.010

Liu, B., Bechtel, A., Sachsenhofer, R. F., Gross, D., Gratzer, R., and Chen, X. (2017). Depositional Environment of Oil Shale within the Second Member of Permian Lucaogou Formation in the Santanghu Basin, Northwest China. Int. J. Coal Geology. 175, 10-25. doi:10.1016/ j.coal.2017.03.011

Liu, B., Sun, J., Zhang, Y., He, J., Fu, X., Yang, L., et al. (2021). Reservoir Space and Enrichment Model of Shale Oil in the First Member of Cretaceous Qingshankou Formation in the Changling Sag, Southern Songliao Basin, NE China. Pet. Exploration Develop. 48, 608-624. doi:10.1016/s1876-3804(21) 60049-6

Mann, U. (1989). Revealing Hydrocarbon Migration Pathways. Geol. Rundsch 78, 337-348. doi:10.1007/bf01988368

McKenzie, J. A. (1985). "Carbon Isotope and Productivity in the Lacustrine and marine Environment," in Chemical Processes in Lakes. Editor W. Stumm (New York: Wiley), 99-118.

Ogrinc, N., Kanduč, T., Krajnc, B., Vilhar, U., Simončič, P., and Jin, L. (2016). Inorganic and Organic Carbon Dynamics in Forested Soils Developed on Contrasting Geology in Slovenia-a Stable Isotope Approach. J. Soils Sediments 16, 382-395. doi:10.1007/s11368-015-1255-7

Pang, X., Li, M., Li, S., and Jin, Z. (2003). Geochemistry of Petroleum Systems in the Niuzhuang South Slope of Bohai Bay Basin. Part 2: Evidence for Significant Contribution of Mature Source Rocks to "Immature Oils" in the Bamianhe Field. Org. Geochem. 34, 931-950. doi:10.1016/s0146-6380(03) 00032-9

Piper, D. Z., and Perkins, R. B. (2004). A Modern vs. Permian Black Shale-The Hydrography, Primary Productivity, and Water-Column Chemistry of Deposition. Chemical Geology. 206, 0-197. doi:10.1016/ j.chemgeo.2003.12.006

Rong, L. X. (2003). Review of Hydrocarbon Migration and Accumulation Dynamics. Nat. Gas Geoence 31, 320-325. (in Chinese with Englsih abstract). doi:10.3969/j.issn.1672-1926.2003.05.002

Rowe, H., Hughes, N., and Robinson, K. (2012). The Quantification and Application of Handheld Energy-Dispersive X-ray Fluorescence (ED-XRF) in Mudrock Chemostratigraphy and Geochemistry. Chem. Geology. 324-325, 122-131. doi:10.1016/j.chemgeo.2011.12.023

Siddiqui, F. I., and Lake, L. W. (1992). A Dynamic Theory of Hydrocarbon Migration. Math. Geol. 24, 305-327. doi:10.1007/bf00893752

Tagiyev, M. F., Nadirov, R. S., Bagirov, E. B., and Lerche, I. (1997). Geohistory, thermal History and Hydrocarbon Generation History of the north-west South Caspian basin. Mar. Pet. Geology. 14, 363-382. doi:10.1016/s0264-8172(96) 00053-0

Yuan, W., Liu, G., Stebbins, A., Xu, L., Niu, X., Luo, W., et al. (2017). Reconstruction of Redox Conditions during Deposition of Organic-Rich Shales of the Upper Triassic Yanchang Formation, Ordos Basin, China. Palaeogeogr. Palaeoclimatol. Palaeoecol. 486, 158-170. doi:10.1016/ j.palaeo.2016.12.020

Zeng, Q., Qian, L., and Liu, D. (2006). Organic Petrological Study on Hydrocarbon Generation and Expulsion from Organic-Rich Black Shale and Oil Shale. ACTA SEDIMENTOLOGICA SINICA 24, 113-122. doi:10.3969/j.issn.10000550.2006.01.015 
Conflict of Interest: The author declares that the research was conducted in the absence of any commercial or financial relationships that could be construed as a potential conflict of interest.

Publisher's Note: All claims expressed in this article are solely those of the authors and do not necessarily represent those of their affiliated organizations, or those of the publisher, the editors and the reviewers. Any product that may be evaluated in this article, or those of the publisher, the editors and the reviewers. Any product that may be evaluated in this article, or claim that may be made by its manufacturer, is not guaranteed or endorsed by the publisher.

Copyright (c) 2021 Bojiang. This is an open-access article distributed under the terms of the Creative Commons Attribution License (CC BY). The use, distribution or reproduction in other forums is permitted, provided the original author(s) and the copyright owner(s) are credited and that the original publication in this journal is cited, in accordance with accepted academic practice. No use, distribution or reproduction is permitted which does not comply with these terms. 